$1(28) / 2015$

\author{
Jolanta Dyrda \\ Uniwersytet Gdański \\ j.dyrda@wp.pl
}

\title{
Zmiany modelu poznawczego uczniów w kontekście prac nad e-podręcznikiem
}

\section{Summary \\ Changes in pupils' cognitive model in the context of work on an e-textbook}

We are witnessing today a phenomenon that might be metaphorically called an explosion of digital technology. The computer and multi-function mobile telephones accompany young people incessantly. A lot of them hardly remember the world free of this kind of implements. G. Small, and G. Vorgan [2011] call today's generation of teenagers "Digital Natives" who acquire knowledge on the Internet, and read no paper-printed information which is seen by them as too antiquated. According to these authors, "Digital immigrants" are newcomers to the digital world. It is adults who have entered the world of new technologies, and who seem mistrustful and sometimes overcome by a sort of "techno-phobia". The difficulty of successful communication today between adults and children, teachers and pupils, has been made even more serious by the arrival of new technologies.

MEN / The Polish Ministry of National Education / have - in their attempt to meet pupils' expectations, and thus make the school a more attractive and modern institution - started work on an e-textbook. My interests in that area have been particularly aroused by the situation of those pupils who have been diagnosed with dyslectic problems. Will the proposed didactic solutions allow for alleviating such problems or, possibly, will they aggravate the situation? In the context of an animated discussion about the project of an e-textbook, I intend to concentrate upon the situation of pupils who experience considerable difficulties in the process of learning at school.

Słowa kluczowe: wielozadaniowość, uzależnienie od technologii, e-podręcznik, orientacja poznawcza, dysleksja

Keywords: multi-tasking, technoholism, e-textbook, cognitive orientation, dyslexia

\section{Współczesne kontrowersje wokół nowych technologii}

Tekst, który chciałabym zaprezentować, został zainspirowany dyskusją toczącą się na spotkaniu Gdańskiej Rady Oświatowej w dniu 14 listopada 2013 roku, po przedstawieniu przez prelegenta efektów prac nad testowaniem e-podręcznika do matematyki dla klasy VI. Wśród członków Rady - przedstawicieli instytucji oświatowych Gdańska - wyraźnie zaznaczyły się dwa stanowiska w kwestii przydatności tego rozwiązania w procesie nauczania. Pierwsze z nich wyrażało entuzjazm dla podjętych przez MEN decyzji o rozpoczęciu prac nad technologicznym usprawnieniem pracy nauczyciela, drugie zgłaszało wąt- 
pliwości związane z technicznymi i merytorycznymi aspektami wprowadzania programu „Cyfrowa szkoła”, w ramach którego powstają e-podręczniki do nauczania na wszystkich etapach kształcenia. Oba stanowiska stanowią doskonały punkt wyjścia do postawienia głównych tez przedstawianego zagadnienia. W ramach podjętej problematyki scharakteryzuję zmiany w funkcjonowaniu poznawczym współczesnego ucznia, traktowane jako kontekst dla omówienia dotychczasowych prac nad e-podręcznikami oraz przeanalizuję długofalowe skutki, jakie praca z e-podręcznikiem niesie dla uczniów ze specyficznymi trudnościami w uczeniu się.

Współcześni młodzi ludzie - w literaturze przedmiotu nazywani „pokoleniem Google’a” (Spitzer 2013) - to urodzeni po 1993 r. użytkownicy nowych technologii, dla których naturalnym sposobem funkcjonowania jest nieustanne korzystanie z internetu za pomocą laptopa, tabletu, smartfonu, co w istocie umożliwia nieprzerwany dostęp do sieci. Wielu uczniów nie przerywa korzystania z Internetu w czasie pobytu w szkole, czyniąc to z zaangażowaniem, przeradzającym się czasami w nałóg.

Charakterystyczna dla młodego pokolenia jest także wielozadaniowość, rozumiana jako korzystanie jednocześnie z wielu urządzeń technicznych. Może to być granie w grę komputerową lub surfowanie $w$ sieci z jednoczesnym odpowiadaniem na sms-y i słuchaniem za pomocą słuchawek muzyki w z odtwarzacza (Small, Vorgan 2011: 107), co skutkuje stanem nieustannego bycia zajętym, czyli zwracaniem uwagi na wszystko, bez skoncentrowania się na czymkolwiek (tamże: 37 ). Odmienne stanowisko w kwestii wielozadaniowości zajmuje E. Miller z MIT. Przeprowadzone przez niego badania wskazują, że $\mathrm{w}$ istocie mamy do czynienia $\mathrm{z}$ ciągłym przechodzeniem od jednego zadania do drugiego, nie zaś z ich jednoczesnym wykonywaniem. Zdaniem badacza prowadzi to do dekoncentracji i obniża sprawność działania (Levitin 2015).

„Cyfrowymi tubylcy” wzrastali w świecie modernizujących się nieustannie nowych technologii, a młode umysły przyswajają więcej, szybciej, inaczej z nieustannie napływających informacji. Swoiste ADHD informacyjne wymaga ciągłego bycia on-line. Szybkie tempo napływania nowych informacji uniemożliwia koncentrację na jednym zadaniu i zakończenie pracy (Small, Vorgan 2011: 107). Przeciążenie informacją i trudność w funkcjonowaniu bez dostępu do urządzeń technicznych powodować może także szczególne zakłócenia w obszarze osobowości. Uzależnienie od Internetu coraz częściej rozpatrywane jest w kategoriach klinicznych, a dyskusja - tocząca się w Stanach Zjednoczonych przed kolejnym wydaniem klasyfikacji chorób i zaburzeń DSMV - dotyczyła możliwości wpisania diagnozy uzależnienia od Internetu do owego rejestru. Przeciwnicy rejestrowania tego uzależnienia jako zaburzenia osobowości wskazują na brak badań neurologicznych, potwierdzających jego istnienie (Aboujaoude 2012: 208), jednak zdesperowani rodzice coraz częściej poszukują profesjonalnej pomocy dla swoich uzależnionych dzieci. W wielu krajach powstają ośrodki pomocy dla „,siecioholików”, jak - stosując duże uproszczenie językowe - określa się to mało rozpoznane uzależnienie. Także w Polsce w publicznych i niepublicznych placówkach powstaja miejsca terapii dla osób korzystających z sieci w sposób niekontrolowany przez nie. W krakowskim Ośrodku Leczenia Zaburzeń Oso- 
bowości w 2002 roku powstat oddział terapeutyczny dla osób z zespołem uzależnienia od Internetu (Mazuś 2014).

Z kolei wśród edukacyjnych skutków życia w cyberprzestrzeni odnotować należy można utrudnienia w odbieraniu informacji z tradycyjnych źródeł: tekstu pisanego, książki, przekazu ustnego. Jednocześnie świat społeczny utożsamia nowoczesność z cyfrową rzeczywistością, na przykład: dodanie przedrostka „e-” zmienia tradycyjnie obecne w języku nazwy w pozornie bardziej atrakcyjne: e-szkoła, e-podręcznik, e-faktura, czy nawet e-Polska. Wirtualność dla młodych ludzi staje się przestrzenią ich świata, przy czym im młodsze osoby, tym bardziej są w niej zanurzone. $Z$ pewnością zjawiska takie stanowią w dużej mierze nieuniknioną konsekwencję rozwoju nowych technologii i postępu technicznego świata. Można przyjąć, że nadszedł czas kultury prefiguratywnej, w którym młode pokolenie staje się najbardziej kompetentne w obszarze wiedzy znaczącej dla dalszego rozwoju (Mead 2000). Dlatego, patrząc pozycji „cyfrowych imigrantów” (Carr 2013), możemy jedynie zwracać uwagę na zagrożenia e-świata.

Choć obiektywnie żyjemy w tym samym świecie, jednak światy zamieszkane przez „cyfrowych tubylców” i „cyfrowych imigrantów” są nieco odmienne. Różnice dotyczą nie tylko sposobu organizacji czasu i gromadzenia informacji, ale także sposobu poznawania świata, przechowywania wiedzy i tworzenia struktur poznawczych. Refleksje nad zagrożeniami płynącymi z nieustannego funkcjonowania on-line toczą się na świecie od jakiegoś czasu, a w Polsce pojawiły się wyraźnie po tłumaczeniach znaczących pozycji literatury przedmiotu. Autorzy, a wśród nich neurolog i psychiatra M. Spitzer oraz badacz zagadnień sieci N. Carr, zwracają uwagę na neurologiczne konsekwencje nieustannego korzystania z nowych technologii i uzależnienie od Internetu, w tym na zmiany aktywności obszarów mózgu, zwłaszcza aktywności synaps (Spitzer 2013: 46). Synapsy, czyli wypustki łączące komórki nerwowe, tworzą pewne szlaki skojarzeniowe i umiejętnościowe (np. orientacja przestrzenna i czasowa). Niekorzystanie z synaps, które są odpowiedzialne za określone rodzaje aktywności, prowadzi do ich zaniku. Na ten proces zwrócił uwagę A. Łuria (1976), podkreślając znaczenie połączeń między wyspecjalizowanymi obszarami w mózgu i wskazując, że liczba i jakość połączeń decydują o możliwości realizowania określonych aktywności umysłowych.

Głębokie przetwarzanie informacji ma istotny wpływ na nasze uczenie się, poznawanie oraz refleksję nad poznawanymi treściami. Ten rodzaj przetwarzania inspiruje do krytycznej analizy w obszarze kultury oraz interioryzacji tych treści, którym nadajemy istotne znaczenie. W tym procesie wiodącą rolę pełni język, będący zarówno narzędziem jak i celem wrastania w kulturę. Kiedy staje się on językiem sms-ów, skrótów (,zw”: zaraz wracam), maili z celowo niegramatycznymi i nieortograficznymi informacjami, może prowadzić do spłycenia możliwości poznawania i przetwarzania informacji. Efektem stać się może między innymi zakłócenie myślenia przyczynowo-skutkowego i chronologicznego, ponieważ teraźniejszość staje się znaczącą kategorią, budowaną przez nieustannie aktualizowane informacje. Natomiast pojęcie przeszłości przestaje mieć znaczenie, bo istnieje wyłącznie jako oś czasu na Facebooku, oznaczając wcześniejsze wpisy. 
W odniesieniu do edukacji szkolnej mamy do czynienia ze swoistym paradoksem: z jednej strony uczniowie posiadają kompetencje technologiczne umożliwiające im szybkie zdobywanie informacji, z drugiej zaś mają problemy z oceną jakości różnych źródeł wiedzy (Spitzer 2013:183; Żylińska 2013:151). Możliwe jest, że trudności w radzeniu sobie z wiedzą i jej przetwarzaniem przejawiają się w charakterystycznych obszarach umiejętności szkolnych. Autorka sprawozdania, podsumowującego wyniki gdańskich szkół osiągnięte w egzaminach zewnętrznych kończących trzy etapy edukacji: szkołę podstawową, gimnazjum i egzamin maturalny, zwróciła uwagę na trudności uczniów z zadaniami egzaminacyjnymi (Przychodzeń 2013). W świetle tego dokumentu większość uczniów klasy VI miała w zakresie zadań z języka polskiego trudności między innymi w obszarze wnioskowania na podstawie informacji z tekstu popularnonaukowego i odczytania jego głównej myśli. Natomiast gimnazjaliści z trudem radzili sobie z umiejętnością interpretowania informacji podanych w różnych tekstach, formułowaniem wniosków, sytuowaniem wydarzeń, zjawisk i procesów w czasie, trudności z uogólnianiem i wnioskowaniem na podstawie informacji wyszukanych w podanych tekstach. Także w części przyrodniczej uczniowie gimnazjum mieli trudności ze wskazaniem w otaczającej rzeczywistości zjawisk opisywanych za pomocą poznanych praw i zależności fizycznych oraz stosowania wiedzy i umiejętności geograficznych w praktyce.

Podane przykłady wskazują, że uczniowie - pomimo szerokiego dostępu do informacji - nie potrafią jej przekształcać i wnioskować na podstawie posiadanych faktów o ogólnych prawidłowościach. Zauważyć można też trudności z przełożeniem informacji ogólnych na przykłady z otoczenia. Można hipotetyczne założyć, że trudności w chronologicznym sytuowaniu wydarzeń wiążą się $\mathrm{w}$ jakimś zakresie $\mathrm{z}$ opisanym wcześniej efektem zanurzenia młodych ludzi w teraźniejszości. Być może zaobserwowane przez OKE trudności uczniów z rodzajem posiadanej przez uczniów wiedzy, jej przetwarzaniem i stosowaniem stanowią efekt działań szkoły, zwłaszcza podających metod kształcenia oraz braku ciekawości poznawczej uczniów spowodowanej formami i treściami edukacji formalnej. Wydaje się jednak prawdopodobne, że składają się na tę sytuację przyczyny tkwiące zarówno w opisanych powyżej sposobach specyficznego przetwarzania informacji przez młode pokolenie jak i niedostosowanych do tych dróg metod edukacji szkolnej.

\section{Orientacja poznawcza jako droga tworzenia orientacji w otoczeniu}

Orientacja poznawcza jest podstawowym sposobem regulującym relacje człowieka z jego otoczeniem, tylko on - jako jedyny spośród organizmów żywych - korzysta z niej w celu maksymalizowania tej orientacji oraz przekształcaniu otoczenia. Działalność człowieka wiąże się ze stałe zwiększającą się zależnością od tworzonego przez niego, coraz bardziej skomplikowanego środowiska (Obuchowski 1970: 10). Mózg człowieka przetwarza informacje według reguł własnej struktury, ale także reguł wytworzonych i wyuczonych w efekcie własnego doświadczenia oraz doświadczenia innych ludzi. Głównym nośnikiem przekazywania reguł jest natomiast język, a posługiwanie się nim wyznacza jako- 
ściowy skok w rozwoju gatunku ludzkiego. W ten sposób pokonana została bariera czasu i przestrzeni, ponieważ możliwość korzystania z doświadczenia innych umożliwiła oderwanie się od dominacji własnego, konkretnego doświadczenia.

K. Obuchowski (1970: 124) przedstawiając dwa układy orientacji poznawczych: konkretne i hierarchiczne, wskazuje na ich znaczenie dla poznawczego funkcjonowania człowieka. Orientacje konkretne są nastawione na wyodrębnianie fragmentów sytuacji, co uniemożliwia całościowe widzenie kontekstu, prowadząc do mozaiki elementów. W układzie tym wyodrębnić można monokonretną i polikonkretną orientację poznawczą. Pierwsza z nich oznacza reagowanie na zewnętrzne bodźce, bez uwzględniania reszty sytuacji. Druga z wymienionych natomiast oparta jest na słowie, ale odnosi się wyłącznie do własnego doświadczenia. Może to oznaczać posługiwanie się pewnymi stereotypami, utwierdzającymi przekonanie o nieomylności własnych sądów. Obraz świata w organizacji orientacji poznawczej na poziomie polikonkretnym charakteryzuje jednopłaszczyznowość i brak myślenia symbolicznego. Z kolei układ hierarchiczny charakteryzuje zdolność do abstrahowania od własnego doświadczenia oraz tworzenie grup pojęć powstających jako efekt zauważania współwystępowania pewnych cech wspólnych. W tym sensie własne doświadczenie może służyć jako materiał do przetwarzania, abstrahowania i hierarchizowania wiedzy (Obuchowski 1970: 124).

Powyższe rozważania prowadzą do refleksji związanej poruszaną w niniejszym tekście problematyką. W świetle koncepcji K. Obuchowskiego (1970), istota uczenia się nie wiąże się z ilością dostarczanej informacji, lecz ze zdolnością do uogólniania, abstrahowania i interpretowania świata. Tak więc uczeń, który w trakcie procesu uczenia się nie zostanie wyposażony w umiejętności hierarchicznego organizowania wiedzy, będzie ją w stanie filtrować tylko przez pryzmat własnego doświadczenia. W tym miejscu analizowane zagadnienie styka się z przywoływanymi wcześniej wątkami płytkiego przetwarzania informacji w orientacji konkretnej oraz głębokim przetwarzaniem informacji w orientacji hierarchicznej. Osoby, które nie wytworzyły takiego sposobu porządkowania obrazu świata, nie są zdolne do uogólniania i abstrahowania informacji. W tym kontekście szkoła staje przed zadaniami rozwijania umiejętności wyszukiwania, selekcjonowania i przetwarzania informacji z różnych źródeł oraz kompetencji krytycznej analizy pozyskanych materiałów za pomocą aktywnych metod pracy (Żylińska 2012: 167). Być może właśnie brak takich działań szkoły jest powodem trudności omawianych wcześniej grup uczniów w realizacji zadań egzaminów zewnętrznych.

Można zatem sformułować tezę, że nadmiar informacji odbieranych przez młodych ludzi nie przekłada się na ich zdolność do refleksyjnego, uogólnionego obrazu świata, a tylko ułatwia gromadzenie licznych, oderwanych od siebie faktów. Nie oznacza to, że nauczanie tradycyjnymi metodami, oparte na zapamiętywaniu oraz odtwarzaniu faktów i informacji, tworzy odmienny obraz świata. Takie nauczanie także prowadzi do konkretnego obrazu świata, dlatego szkoła - niezależnie od tego, czy pozostanie przy dotychczasowym sposobie nauczania, czy też stanie się e-szkołą z nowoczesnym oprzyrządowaniem - nie zmieni kompetencji uczniów bez zmiany podstawowego celu kształcenia, jakim stać się 
może przygotowanie młodych ludzi samodzielnego myślenia, umysłowego wysiłku nad interpretowaniem, uogólnianiem i tworzeniem hierarchicznego obrazu świata.

\section{Prace nad e-podręcznikiem w Polsce}

Tymczasem władze oświatowe lokują unowocześnienie szkoły w procesie digitalizacji podręczników. Od kilku lat trwają intensywne prace nad zastosowaniem nowoczesnych narzędzi elektronicznych w edukacji szkolnej. Zarówno próby uzupełniania nauczania e-learningiem za pomocą platform edukacyjnych, jak i prace Ministerstwa Edukacji Narodowej nad tworzeniem, testowaniem i wprowadzaniem podręczników w formie elektronicznej stanowią przykłady pozornego otwierania się szkoły na nowe rozwiązania edukacyjne. Pozornego, gdyż nowa forma podręcznika, bardziej atrakcyjna, może niewiele zmienić w obszarze metod pracy szkolnej. Możliwość wydruku e-podręcznika dostępnego formie PDF może też dla nauczycieli stanowić okazję do pracy na jego papierowych wersjach.

Technologie informacyjno-komunikacyjne, określane w dokumentach ministerialnych skrótem TIK, mają wprowadzić szkołę w erę powszechnego cyfrowego świata. W ramach projektu MEN „Cyfrowa szkoła” testowano w roku szkolnym 2012/13 e-podręcznik do matematyki dla klasy VI. Projekt objął 400 szkół z całej Polski, które były w stanie sfinansować $20 \%$ wkładu własnego w sprzęt. Ministerstwo zabezpieczyło na ten cel $50 \mathrm{mln}$ złotych. Harmonogram prac nad tworzeniem e-podręczników zakłada, że wszystkie powinny być gotowe do czerwca 2015 roku. 26 czerwca 2014 roku przedstawiono dwa kompletne podręczniki do informatyki i matematyki dla klasy I liceum i technikum oraz podręcznik matematyki dla klasy IV szkoły podstawowej. Zaangażowanie przez MEN środków finansowych oraz organizacyjnych w prace nad tworzeniem e-podręczników wskazuje na wybrany kierunek poszukiwania nowych rozwiązań edukacyjnych w tym właśnie obszarze.

\section{Kompetencje kluczowe a zmiany edukacyjne}

Strategie zmian w systemach szkolnych wielu krajów Europy wpisują się w wytyczne Unii Europejskiej sformułowane w postaci kompetencji kluczowych w procesie uczenia się przez całe życie, określonych zaleceniem Parlamentu Europejskiego i Rady Europy $\mathrm{z}$ dnia 18 grudnia 2006. Kompetencje kluczowe są w tym dokumencie definiowane jako połączenie wiedzy, umiejętności i postaw odpowiednich do sytuacji w następujących obszarach:

1. porozumiewanie się w języku ojczystym,

2. porozumiewanie się $w$ języku obcym,

3. kompetencje naukowo techniczne,

4. kompetencje informatyczne,

5. umiejętności uczenia się,

6. kompetencje społeczne i obywatelskie, 
7. inicjatywność i przedsiębiorczość,

8. świadomość kultury i ekspresja kulturalna.

W odniesieniu do edukacji przedstawione kompetencje dotyczą wszystkich poziomów kształcenia. Dokument podkreśla, że są one szczególnie ważne dla osiągania przez człowieka celów społecznych już w czasie pobierania nauki, choć głównie chodzi o urzeczywistnienie własnych celów społecznych w życiu dojrzałym. Ta perspektywa nakłada na szkołę obowiązek takiego realizowania zadań edukacyjnych, aby stały się one kapitałem życiowym ucznia.

Można zatem przyjąć, że prace w ramach projektu „Cyfrowa szkoła” stanowią próbę kształcenia kompetencji kluczowych przez rozszerzanie środowiska edukacyjnego o nowe technologie. Jest to zbieżne także z informatyzacją wielu obszarach współczesnego codziennego życia. Nowy nurt edukacyjny, zanurzony w cyfrowym świecie, G. Siemens (2004) nazywa konektywizmem, sugerując potrzebę wzrastającego powiązania nauczania ze środkami technicznymi. Autor wskazuje też, że nieustannie zmieniające się informacje uzasadniają konieczność zmiany modelu uczenia się, a podstawową kompetencję ucznia stać się powinno rozpoznanie, które informacje są istotne, a które bezwartościowe i bezużyteczne. Na konektywizm składają się następujące zasady (Siemens 2004):

1. Nauka i wiedza opiera się na różnorodności poglądów.

2. Uczenie się jest procesem nabywania umiejętności korzystania z różnych źródeł informacji.

3. Tworzenie i utrzymywanie połączeń z bazami wiedzy jest niezbędne dla procesu uczenia się.

4. Etap podejmowania decyzji jest etapem procesu uczenia się, gdyż wybór i rozumienie napływającej informacji stanowi kluczową umiejętność, pozwalającą ocenić, co jest istotne i przydatne, co zaś bezwartościowe.

Poglądy G. Siemensa oraz jego koncepcja konektywizmu jako modelu edukacji wskazuje na utożsamianie wiedzy z informacją, co jest zabiegiem umożliwiającym myślenie, że wiedza może znajdować się poza uczniem, w zewnętrznych bazach wiedzy. Takie stanowisko pozostaje w wyraźnej sprzeczności ze znaczeniem, jakie przypisuje wiedzy K. Obuchowski, wskazując na jej udział w tworzeniu struktury poznawczej człowieka. W jego ujęciu interioryzacja wiedzy sprzyja powstawaniu obrazu świata $\mathrm{w}$ organizacji konkretnej lub hierarchicznej, dlatego wiedza, która pozostaje jako zewnętrzna, nieustannie dostępna on-line, jest bez znaczenia dla procesów powstawania wewnętrznej reprezentacji poznawczej.

\section{Uczniowie ze specyficznymi trudnościami w uczeniu się a nowe technologie}

Wśród uczniów szkoły znajdują się tacy, którym podstawowe umiejętności szkolne: pisanie, czytanie i liczenie, sprawiają szczególne trudności. Termin specyficzne trudności w uczeniu się (specific learning disability) obejmuje zarówno uczniów z dysleksją, jak i innymi zakłóceniami procesu uczenia się. Jednak dysleksja jest najlepiej opracowanym 
i najczęściej występującym rodzajem tego typu trudności. W wąskim znaczeniu rozumie się ją jako trudności w czytaniu, w szerszym - jako ogólne określenie obejmujące także inne specyficzne trudności w posługiwaniu się językiem, takie jak: dysortografia, czyli specyficzne trudności w opanowaniu poprawnej pisowni w sensie ortograficznym, oraz dysgrafia, oznaczająca trudności w opanowaniu właściwego poziomu graficznego pisma. Wśród specyficznych trudności wyróżnia się także dyskalkulię jako specyficzne trudności w uczeniu się matematyki (Krasowicz-Kupis 2009: 36).

Współczesne koncepcje przyczyn trudności dyslektycznych koncentrują się na zagadnieniu rozwoju funkcji językowych jako znaczących dla procesu czytania i pisania. Dzieci z osłabionym rozwojem mowy w znacznie większym stopniu obciążone są ryzykiem trudności w czytaniu i pisaniu (tamże: 112). W świetle badań nad dysleksją można zauważyć, że uczniowie z tego typu trudnościami doświadczają także trudności w innych obszarach językowego porozumiewania się oraz komunikacji (Borkowska 1998). W tym kontekście zasadne staje się pytanie o kierunki pracy terapeutycznej z uczniami z dysleksją, zwłaszcza o wykorzystanie w pracy nowych technologii informacyjnych i komunikacyjnych.

Niektórzy badacze zagadnienia podkreślają szczególne walory TIK we wspieraniu osób z dysleksją, zwłaszcza ułatwianie czytania, pisania, organizacji i planowania (Krasowicz-Kupis 2009: 209). Niewątpliwie nowe technologie wspomagają proces diagnozy trudności o charakterze dyslektycznym oraz urozmaicają zajęcia terapeutyczne. Jednak należy pamiętać o językowym (pojęciowym, narracyjnym) oraz komunikacyjnym obszarze trudności współwystępującymi z trudnościami w czytaniu i pisaniu. Wydaje się, że nadmierne stosowanie nowych technologii nie przyczynia się do rozwoju tych umiejętności, o czym pisałam we wcześniejszych częściach tekstu. Być może należałoby w terapii pedagogicznej uczniów z dysleksją skupić się raczej na rozwoju języka, frazeologii i umiejętności opowiadania. Tych umiejętności uczeń nie nabędzie, posługując się nowymi technologiami, lecz w kontakcie z nauczycielem lub terapeutą posiadającym znaczną świadomość roli rozwoju języka w szkolnych i pozaszkolnych działaniach edukacyjnych oraz komunikacyjnych. Ponadto, to właśnie umiejętności językowe i komunikacyjne odgrywają kluczową rolę w procesie nabywania kompetencji kulturowych (Dyrda 2004: 40).

Podjęte w przedstawianym tekście zagadnienia są bardziej podjęciem próby krytycznego namysłu, niż zmierzają do jednoznacznych odpowiedzi na pytania o pozytywne lub negatywne konsekwencje zanurzenia edukacji w świecie nowych technologii. Wydaje się, że główny problem edukacji szkolnej koncentruje się wokół pytania: Jakiej wiedzy i umiejętności potrzeba uczniom wobec wyzwań przyszłego świata, który będzie ich dorosłością? Możliwość zachowania przez nich samodzielnego i krytycznego myślenia stanowi wyzwanie dla szkoły. Zarówno zwolennicy jak i krytycy nowych technologii w szkole nie mogą pozostać obojętni wobec faktu, że samo ich stosowanie nie stanowi o innowacyjnej czy rewolucyjnej zmianie edukacyjnej. 


\section{Literatura}

Aboujaoude E. (2012), Wirtualna osobowość naszych czasów. Mroczna strona e-osobowości. Kraków, Wydawnictwo Uniwersytetu Jagiellońskiego.

Borkowska A. (1998), Analiza dyskursu narracyjnego u dzieci z dysleksją. Lublin, Wydawnictwo UMCS.

Carr N. (2013), Ptytki umyst. Jak internet wplywa na nasz mózg. Gliwice, Helion.

Dyrda J. (2004), Style uczenia się dzieci dyslektycznych a wymagania poznawcze szkoły. Gdańsk, Wydawnictwo Uniwersytetu Gdańskiego.

Krasowicz-Kupis G. (2009), Psychologia dysleksji. Warszawa, PWN.

Levitin D.J. (2015), Why the modern world is bad for your brain. http://www.theguardian.com/ science/2015/jan/18/modern-world-bad-for-brain-daniel-j-levitin-organized-mind-informationoverload [16.08.2014].

Łuria A. (1976), Podstawy neuropsychologii. Warszawa, PZWL.

Mazuś M. (2014), Zaplątani. http://www.polityka.pl/jamyoni/1594499,1,siecioholizm-trzeba-leczyc.read [16.08.2014].

Mead M. (2000), Kultura i tożsamość. Studium dystansu międzypokoleniowego. Warszawa, PWN.

Obuchowski K. (1970), Kody orientacji i struktura procesów emocjonalnych. Warszawa, PWN.

Przychodzeń B. (2013), Analiza wyników egzaminów zewnętrznych w 2013 roku. Miasto Gdańsk. Materiał dla Gdańskiej Rady Oświatowej, 14 listopada 2013 r.

Siemens G. (2004), Connectivism: A learning Theory for the Digital Age. http://www.elearningspace.org/Articles/connectivism.htm [16.08.2014].

Small G., Vorgan G. (2011), i Mózg. Jak przetrwać technologiczną przemianę współczesnej umystowości. Poznań, Vesper.

Spitzer M. (2013), Cyfrowa demencja. W jaki sposób pozbawiamy rozumu siebie i swoje dzieci. Słupsk. Wydawnictwo Dobra Literatura.

Żylińska M. (2013), Neurodydaktyka, czyli nauczanie i uczenie się przyjazne mózgowi. Toruń. Wydawnictwo Naukowe UMK. 